DEVELOPING WRITING MATERIALS FOR THE FIRST GRADE STUDENTS AT SMA NEGERI 1 BINJAI

\title{
AN ARTICLE
}

Submitted in Partial Fulfillment of the Requirements for the Degree of Sarjana Pendidikan

By:

FEBY MAULIDA NASUTION

Registration Number: 2133321022



ENGLISH AND LITERATURE DEPARTMENT

FACULTY OF LANGUAGES AND ARTS

STATE UNIVERSITY OF MEDAN

2017 


\section{ARTIKEL \\ DEVELOPING WRITING MATERIALS FOR THE FIRST GRADE STUDENTS AT SMA NEGERI 1 BINJAI}

Disusun dan Diajukan oleh:

Feby Maulida Nasution NIM. 2133321022

Telah diverifikasi dan dinyatakan memenuhi syarat untuk diunggah pada jurnal online

Medan, November 2017

Menyetujui

Dosen Pembimbing Skripsi I

Dosen Pembimbing Skripsi II
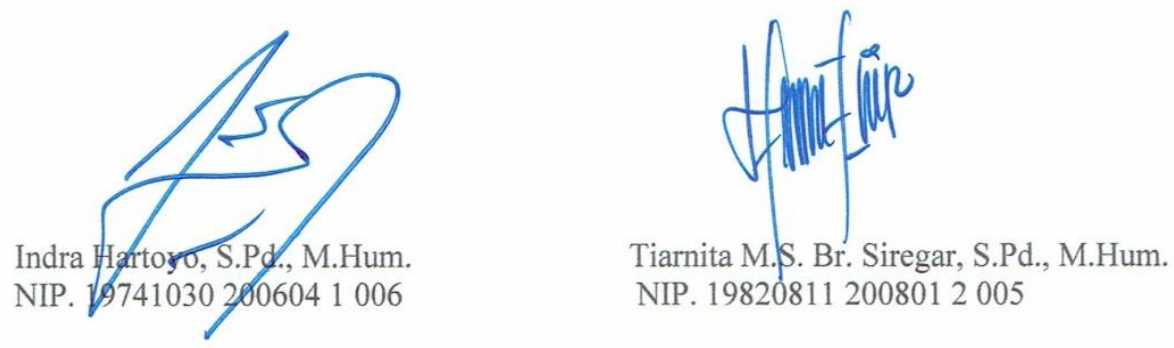

NIP. 198208112008012005

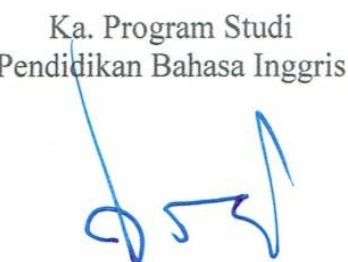

Nora Ronita Dewi, S.Pd., S.S., M.Hum.

NIP. 198005222008122003 


\title{
DEVELOPING WRITING MATERIALS FOR THE FIRST GRADE STUDENTS AT SMA NEGERI 1 BINJAI
}

\author{
*FebyMaulidaNasution \\ **IndraHartoyo \\ **Tiarnita Maria Sarjani Br. Siregar
}

\begin{abstract}
The objectives of this study are to investigate the relevant English writing materials for the first grade students at SMA Negeri 1 Binjai and to develop the relevant English writing materials through contextualization for the first grade students at SMA Negeri 1 Binjai. This research was conducted based on educational research and development (R\&D) through three steps: 1) evaluation and need analysis, 2) course design, and 3) materials validation. The subjects of this study were the first grade students at SMA Negeri 1 Binjai and the English teacher at SMA Negeri 1 Binjai. The instruments in this study were questionnaire and the question sheet. Questionnaire was administered to the students, meanwhile the question sheet was used while interviewing the English teacher. The data which were gathered from the evaluation and need analysis were analyzed in the descriptive analysis, and the result of the expert judgment about the quality of the developed materials used quantitative descriptive analysis. The result of this study was a coursebook of writing materials based on contextualization. The contextualized materials consisted of three chapters which were related to the students' real experience. The first chapter was my lovely people, the second chapter was my amazing city and the third chapter was the memorable moments in my life. Based on the experts' judgment result, the score of the developed materials was 90 which belong to excellent category, since the range was (80-100).
\end{abstract}

Key words: Research and Development (R\&D), Contextualization, Writing Stages, Writing Materials.

\footnotetext{
*Graduate Status

**Lecturer Status
} 


\section{INTRODUCTION}

\section{Background of the Study}

In teaching and learning process, the using of good and appropriate learning materials can help and support the successfulness of presenting materials, because the better quality of learning materials causes learning process runs more effectively and productively. Learning materials are used as one of learning sources which facilitate students with a lot of information in various learning topics. Therefore, the contents or topics in the learning materials should be considered.

According to Tomlinson (2010: 5) learning materials must apply contextualization, because the materials will invite students' motivation in learning and the students will easily visualize and connect their own experiences to the learning material. As the result, the student will enjoy the learning process.

According to Afzal et al (2010) students' motivation is the element that leads students' attitude towards learning process, and academic performance is positively influenced by students' motivation. If the students are not interested in learning the topics, they will not write appropriately, then they are not able to improve their writing skill. As the result they will have low competence in writing, moreover they will get low score in learning and the learning objective will be hard to be achieved.

As one of an important skills in English, writing requires special attention in presenting the materials. The learning materials must be able to provide a lot of 
various information about writing in English and also able to guide the learners improve their writing skill.

According to Hyland (2002:91) writing is a recursive process which consists of some stages namely prewriting, writing, editing, revising, publication and appreciation. All of the stages are aimed to improve students writing skill through some revisions and help the learners to evaluate how well they have developed a text to give meaningful information for the readers.

Unfortunately, not all of the students are able to write genre writing well although the writing process or writing stages have been provided. Based on an observation which conducted on $7^{\text {th }}$ April 2017 at SMA Negeri 1 Binjai. It was found that more than $50 \%$ students still got low score although the writing stages had been provided in the materials. The score was lower than the $K K M(75)$. This data were obtained based on teacher's clarification and the observation of students' score while writing some types of genre writing include descriptive text and recount text in their exercise books.

Many students were not motivated and interested in writing because the contents of the selected topics in the coursebook did not apply contextualization. All of the topics are not related to students' real experiences and environments. This situation influenced students to copy and to imitate their friends' creation to finish their task easily. As the result, they were lazy to write and they had low competence in writing.

Based on the implementation of the syllabus in curriculum 2013, the first grade students only focus on two types of texts in writing skill, they are: 
Descriptive text and Recount text. In the existing materials, the coursebook which was used by the first grade students at SMA Negeri 1 Binjai cannot provide specific contextualized materials in writing. The materials were still too general to involved students' personal experience. The uncontextualized writing materials involve two chapters. The first chapter was about descriptive text material. The topics are "Niagara Fall, TajMahal and TanjungPuting National Park". All these topics were not contextualized with students' environments even their own personal experiences. No students ever go there. They tried to describe places where they never visit yet. It would be better if the materials were about places around them, liked their home, tourists spot in Binjai and etc. The material would be more concretely.

The second writing material was recount text, the topics were about the historical events liked“ The battle of Surabaya”, “ Biography of B.J. Habibie and Cut NyakDhien". These topics were good to build students' nationalism, unfortunately, these topics could not connect students' real experience to the learning process. These topics only let the students to imagine the historical events through the past history that they ever heard for several times. This condition was obviously contradictable with the main concept of contextualized materials.

Meanwhile the basic competence of writing recount text for the first grade students is not specifically mentioned to retell the historical events but the materials must able to provide simple recount text about event or experience 
based on appropriate contexts which can be related to students' real life or students' real experience.

The preliminary data showed that, there was a connection among uncontextualized topics, students' motivation and students' achievement toward students' competence in writing. In addition, curriculum 2013 emphasize an active learning process, therefore contextualized material was absolutely needed to provide in writing material to support the existing materials.

Because of that reasons, the development of writing materials for the first grade students at SMA Negeri 1 Binjai is needed. The writing materials for the first grade students at SMA Negeri 1 Binjaiwere needed to be developed by implementing contextualization in designing the materials and still providing writing stages within it. Therefore, the developed materials are expected to be able to motivate the students to develop their writing skill actively in order to support a successful achievement of the learning objectives.

\section{REVIEW OF LITERATURE}

\section{The Nature of Writing}

Some experts have explained writing into various terms, According to Horvath (2001: 5) writing is among the most complex human activities. It involves the development of designing an idea, the capture of mental representations of knowledge, and of experience from a subjects.

Hyland (2002: 23) adds the definition of writing as developmental process. It means that when we write, we develop a topic into complex information by 
providing one main idea and give some supporting sentences to develop that main idea.

\section{Material Development}

Tomlinson (2012: 143-144) explains material development is refers to all the processes that made by practitioners who produce or use that materials for language learning, including materials evaluation, their adaptation, design, production, exploitation and research. This material development is aimed to support the learning process positively to be more efficient and effective, so that the weakness of the existing materials can be improved to help the achievement of the learning objectives.

\section{Developing Writing Material Based on Contextualization}

Contextualization is a diverse family of instructional strategies in designing materials which more seamlessly link the learning of foundational or basic skills with academic or occupational content by focusing teaching and learning process on concrete applications in a specific context which are related and designed to students' interest and students' experience. This term can be seen as a form of "deep learning" where the learning process is directly reference to real world events and practices (Mazzeo et al, 2010; Berns and Erickson, 2001; as cited in (Perin: 2011).

\section{Need Analysis}

Needs analysis can be defined as kinds of activities that involve gathering and collecting information and relevant data which are used as the basis for developing teaching materials congruent with particular learners or groups' needs. 
It is also aimed to finding out what learners (practitioners) know, do and what they need to learn or do (Graves, 2000; Brown, 2004, Graves; 1996) as cited in (Dirgeyasa and Ansari, 2015).

\title{
RESEARCH METHODOLOGY
}

\author{
Research Design
}

This research was conducted by using Educational Research and Development (R \& D Research) which proposed by Borg, Gall and Gall (2003). The steps of the Educational Research and Development (R \& D Research) were simplified into three, they are Evaluation and need analysis, Course design and Materials validation.

\section{Subjects of the Study}

The Subjects of this research were English teacher and 38 first grade students in language class at SMA Negeri 1 Binjai.

\section{Technique and Instruments for Collecting Data}

\section{a. Techniques}

The data of this research were gathered by using two techniques. The first technique was using questionnaire and the second technique was conducting interview.

\section{b. Instruments}

The instruments which were used in this research were questionnaire and the question sheet. The questionnaires were designed based on theory of Hutchinson 
and Waters about need analysis (1987: 55-63) and they were administered to the students in evaluation and need analysis stages in order to find out the data of students' necessities, lacks and wants.Meanwhile question sheet was used to ask some questions to the English teacher to get deeper infomation about students' necessities, lacks and wants in learning.

\section{Technique of Analyzing data}

To give a good understanding about the findings of this research, the data which had been gathered in this study were analyzed by using descriptive analysis by calsulating the score in each statements in the questionaire and calculating the final score to get conclusion about students' necessities, lacks and wants toward the learning materials in evaluation and need analysis stages.

\section{RESEARCH FINDINGS}

1. In Evaluation stages, it was found that there are 3 learning topics which were not related to the contextualization, because those topics are not related to students' experiences or students' environments. The differences of the topics can be seen below. Based on the questinnaire only $31 \%$ students who agreed that the existing materials was very interesting and able to improve their interests in writing. Meanwuhile 69\% students who disagreed with this statement.

2. In conducting Need Analysis by administerring questionnaire, it was found that $76 \%$ students stated that they needed contextualized materials which related to their experiences and their environments.

3. There were $82 \%$ students who stated that the contextualized materials help them to understanding learning materials easily. 
4. There were $75 \%$ students who stated that they need writing materials of descriptive text which related to their lovely people in/or places around my town.

5. There were $85 \%$ students who stated that they need writing materials of recount text which related to their past personal experience.

6. Based on the result of the questionnaire, the existing materials were developed into some topics. The data can be seen below.

\begin{tabular}{|c|c|c|c|}
\hline No. & Existing Topics & No. & Developed topics \\
\hline 1. & $\begin{array}{c}\text { Niagara Fall, TajMahal and } \\
\text { TanjungPuting National Park }\end{array}$ & 1. & My Amazing City \\
\hline 2. & $\begin{array}{c}\text { No topics about describing } \\
\text { people }\end{array}$ & 2. & My Lovely People \\
\hline 3. & $\begin{array}{c}\text { The battle of Surabaya", } \\
\text { "Biography of B.J. Habibie and } \\
\text { Cut NyakDhien }\end{array}$ & 3. & $\begin{array}{c}\text { The Memorable Moment in } \\
\text { My Life }\end{array}$ \\
\hline
\end{tabular}

7. To prove the effectiveness of the contextualized materials, the developed materials in this study had been validated by two experts and based on the validated score, the developed materials got 90. It was belonged to the "Excellent" category. It means that the developed materials were suitable and properly covered students need in writing materials and the aims of this study were achieved successfully

\section{CONCLUSIONS AND SUGGESTIONS}

\section{A. Conclusions}

Learning material is one of the most important elements that should be prepared in the learning process. Therefore, the quality and the ability of the materials to cover students' need in learning must be considered. The materials must enable the students to improve their competences in learning, enrich them 
with a lot of information through some exploration in the learning process and enable the students to connect their own life experience towards the learning materials to improve students' interest in learning. This term is known as contextualization. This materials made the students became more creative, expressive and interactive in developing and easily transferring their ideas into the writing product, because the product of the writing is based on their true stories.

\section{B. Suggestions}

\section{Teachers}

It is suggested that the English teacher should be more responsive with the students' need in conducting the learning process. Teachers should be able to design or to develop the writing materials to improve students' interest in learning.

\section{Students}

Students must be able to explore much information by themselves in order to enrich their knowledge. They need to explore much sources of information like accessing information from internet, magazine, newspaper even other textbooks if they find that the existing materials cannot provide information completely.

\section{Other Researchers}

Other researchers should be motivated to develop the learning materials. This study may be used as a reference. Moreover they have to find a lot of references in developing writing materials to support them in conducting the same research, so that the quality of their research will be better than this research. 


\section{REFERENCES}

Afzal, Hasan et al. 2010. A Study of University Students' Motivation and Its Relationship with Their Academic Performance.International Journal of Business and Management. 5 (4)

Borg, W.R., Gall, M.D., and Gall, J.P. 2003. Educational Research: An introduction seventh edition. Boston: Ablongman.

Dirgeyasa, Wy. I and Khairil Ansari. 2015. The study of Need Analysis of Tourism Topics and English Linguistic Featuers through Local-Based Content at the Golden Triangle Tourism Destination in North Sumatra Province Indonesia. Asian EFL Journal. 86.8 (7)

Horvath, Jozsef. 2001. Advanced Writing in English as A Foreign Language. Hungary : Lingua Franca Csoport

Hutchinson, T \& Waters, A. 1987.English for Specific Purposes. Cambridge: Cambridge University Press.

Hyland, Ken. 2002. Teaching and Researchingwriting.London: Pearson Education.

Perin, Dolores. 2011. Facilitating Student Learning Through Contextualization. New York: Columbia University

Tomlinson, B. 2010.Principles and procedures for self-access materials.SiSAL Journal, $1(2), 72-86$.

Tomlinson, B. 2012.Materials development for language learning and teaching.Journal of Language Teaching, 45.2, 143-179. 